\title{
Effects of Nitrogen Application on the Growth and Yield of Quinoa under Saline Conditions in Northern Vietnam
}

\author{
Dinh Thai Hoang ${ }^{1}$, Dang Thi Phuong Anh', Luu Hue Nhan² \& \\ Nguyen Viet Long ${ }^{1}$
}

${ }^{1}$ Faculty of Agronomy, Vietnam National University of Agriculture , Hanoi 131000, Vietnam

${ }^{2}$ Department of Production, Military Academy of Logistics, Hanoi 131000, Vietnam

\begin{abstract}
This study aimed to determine the optimum nitrogen application rate for quinoa in saline soils. Two experiments were conducted: (i) the first experiment was under artificial saline conditions with the two factors of saline regime (stressed and non-stressed) and nitrogen application level $\left(0,30,60,90\right.$ and $\left.150 \mathrm{~kg} \mathrm{~N}^{-1}\right)$ in net-houses located in Gia Lam, Hanoi; and (ii) the second experiment was under natural field saline conditions with the two factors of quinoa cultivar (Atlas and Moradas) and nitrogen application level (0, 30, 60, 90, and $150 \mathrm{~kg} \mathrm{~N} \mathrm{ha}^{-1}$ ) in the coastal areas of Hai Hau, Nam Dinh province. Data were collected for growth duration, insect and disease infestations during the growth period, and various growth parameters and yield components at harvest. The results showed that saline stress reduced the growth and yield parameters, but did not affect the quinoa growth duration of the investigated quinoa cultivars. In both experiments, the growth parameters and yield components increased according to the increase of the nitrogen application rates from 0 to $90 \mathrm{~kg} \mathrm{~N} \mathrm{ha}^{-1}$, then decreased when the nitrogen rates were higher. The results suggested that $90 \mathrm{~kg} \mathrm{~N}$ ha $^{-1}$ was the optimum nitrogen application dose for quinoa growth and development under saline soil conditions.
\end{abstract}

\section{Keywords}

Nitrogen, growth, quinoa, saline stress, yield

\section{Introduction}

Currently, over one million hectares of cultivated land in the

Received: September 6, 2020

Accepted: November 22, 2020

Correspondence to nvlong@vnua.edu.vn 
replanting and using freshwater for desalting (Nguyen Viet Long, 2016a). Under the adverse impacts of climate change, crop production under these conditions has become more severe due to the increase of soil salinity and the scarcity of freshwater used for irrigation and saline drainage. One of the solutions to promote agricultural production in these saline areas is using salt-tolerant plants that can grow well with little or without using freshwater as a desalting strategy.

Quinoa (Chenopodium quinoa Wild) is a highly adapted crop capable of growing under stressful conditions. It is known as a "golden food" that has many desirable features such as being highly delicious, adequately nutritious, safe, and environmentally friendly. Quinoa grain contains sufficient amounts of essential amino acids with rich energy and high-quality protein, has high mineral and fiber contents and low fatty oil content, and lacks gluten, which can cause dangerous human diseases (FAO, 2011). Therefore, it is considered a functional food that helps prevent heart disease and improves bone health (FAO, 2013).

In the Northern part of Vietnam, from 1986 to 2000, quinoa was grown using the HV1 variety, which has a grain yield of 14.0 to 20.6 quintal ha ${ }^{-1}$ (Trinh Ngoc Duc, 2001). Bertero et al. (2004) pointed out that quinoa adapted well to Vietnam's conditions with a yield higher than those in several native regions. Also, previous studies introduced varieties that have the ability to be cultivated in the saline areas in the Northern provinces of Vietnam such as Moradas, Verde (Nguyen Viet Long, 2016a), and Red (Nguyen Viet Long, 2016b). Besides using better quinoa varieties, quinoa production can be improved through other strategies such as proper nitrogen fertilizer application. Trinh Ngoc Duc (2001) proposed a fertilizer procedure for quinoa with an amount of 10 tons of manure $+60-80 \mathrm{~kg} \mathrm{~N}+60$ $80 \mathrm{~kg} \mathrm{P}_{2} \mathrm{O}_{5}+30-40 \mathrm{~kg} \mathrm{~K}_{2} \mathrm{O}$ ha $^{-1}$. In Hanoi, under non-stress conditions, Dinh Thai Hoang et al. (2015) reported that at the optimum dose of 90 $\mathrm{kg} \mathrm{N} \mathrm{ha}{ }^{-1}$, quinoa produced the highest growth and yield. However, there is no study about the nitrogen application for quinoa grown in saline soils in Vietnam. The current study was carried out to evaluate the effects of nitrogen application on the growth and yield of quinoa to suggest the optimum nitrogen dose for quinoa production in saline conditions in Northern Vietnam.

\section{Materials and Methods}

The study was conducted with two experiments. The first experiment evaluated the effects of salt stress and nitrogen application dose on the growth and yield of quinoa in the 2017 winter cropping season in Gia Lam district, Hanoi, Vietnam. The pot experiment was conducted under net-house conditions at the Faculty of Agronomy, Vietnam National University of Agriculture. The two-factor experiment was designed using a randomized complete block design (RCBD) with five replications. The first factor was the nitrogen level at the five rates of $0,30,60,90$, and $150 \mathrm{~kg}$ $\mathrm{N} \mathrm{ha}^{-1}$. The second factor was the salinity level, either non-stressed or moderately stressed. The quinoa variety Atlas, introduced from the Netherlands, was used in this experiment. A $2 \mathrm{~kg}$ mixture of Red River alluvial soil, rice husk ash, and Song Gianh microbiological fertilizer at a ratio of 8.5:1.0:0.5 by weight was used to fill the plastic pots $(14 \times 12 \times 20 \mathrm{~cm}$ in height, lower-side diameter, and upper-side diameter, respectively). Then, twenty quinoa seeds were sown in each pot. After germination, young seedlings (at the 34 leaves stage) were thinned to keep 5 healthy seedlings pot $^{-1}$. The amount of fertilizer was calculated and applied for each pot with a base of $500 \mathrm{~kg}$ lime $+60 \mathrm{~kg} \mathrm{P}_{2} \mathrm{O}_{5}+60 \mathrm{~kg} \mathrm{~K}_{2} \mathrm{O} \mathrm{ha}^{-1}$ (Dinh Thai Hoang et al., 2015). Whole lime and phosphate amounts were well-mixed with the soil as a basal application before sowing. Nitrogen was applied at three distinctive time points: the 5-7 full leaves stage, two weeks later, and one month after the first application. Potassium was applied two times at the flowering stage and one week after the first application. Fresh water was applied as needed to support plant growth from sowing to harvest. For the saline stress treatment, a $\mathrm{NaCl}$ solution $(100 \mathrm{mM})$ was used to replace the freshwater for 15 days from 30 to 45 days after planting. 
The second experiment evaluated the effects of nitrogen application on the growth and yield of quinoa under saline conditions in the 2018 spring cropping season in Hai Hau district, Nam Dinh province, Vietnam. Two quinoa varieties, Atlas and Moradas, introduced from the Netherlands were used. The two-factor experiment was designed using a randomized complete block (RCBD) with three replications. The first factor was the quinoa variety (Atlas and Moradas), and the second factor was the nitrogen application dose (same five doses as in the first experiment). The experimental soil was a moderate saline soil with the chemical properties at the $0-40 \mathrm{~cm}$ depth as $0.17 \%$ of total $\mathrm{N}, 7.65 \mathrm{mg}$

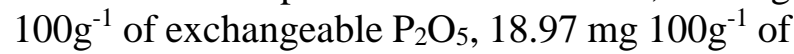
$\mathrm{K}_{2} \mathrm{O}, 2.08 \mathrm{mS} \mathrm{cm}^{-1}$ of EC, 1.25 of total dissolved salts, and a pH of 7.3. The area of each experimental plot was $15 \mathrm{~m}^{2}$. The seeds were sown with a distance of $60 \times 15 \mathrm{~cm}$ between the rows and plants. Nitrogen was applied with a base dose of 10 tones manure $+90 \mathrm{~kg} \mathrm{P}_{2} \mathrm{O}_{5}$ and $90 \mathrm{~kg} \mathrm{~K} \mathrm{~K}_{2} \mathrm{O} \mathrm{ha}^{-1}$. Whole manure and phosphate, and $1 / 3$ the amount of potassium were applied as the basal dose before sowing. At 35 days and 70 days after sowing, a half dose of nitrogen and 1/3 dose of potassium were applied.

The target parameters collected included the growth duration from sowing to emergence, flowering, and harvest. At harvest, the data for the growth parameters, including plant height, plant diameter, number of leaves/main stem, number of branches/plant, dry matter accumulation, head panicle length, 1000-seed weight, and individual yield, were collected. For the field experiment, the actual yield at harvest, the lodging resistance, and the infection rates of black cutworm and clover worm were also determined during the growth stages. The methods to determine the target parameters followed the descriptors for quinoa and its wild relatives (Bioversity International, 2013).

The data were subjected to analyses of variance (ANOVA) according to a randomized complete block design for two-factor experiments using IRRISTAT 5.0 program. The sources of variation included variety/saline level, $\mathrm{N}$ level, replication (block) and interaction among the main variables. Least Significant
Difference (LSD) at significant level of 5\% was used to compare means.

\section{Results}

Effects of salt stress and nitrogen application on the growth duration of quinoa under nethouse conditions in the 2017 winter cropping season in Gia Lam, Hanoi

The results for the effects of salt stress and nitrogen application to the growth duration of the quinoa variety Atlas are shown in Table 1. These results indicate that there were no differences in the time from sowing to emergence and flowering, but the time from sowing to harvesting of quinoa in the stress treatment was longer (2.0 days) than that in the non-stress treatment. Similar results were found in the effects of the nitrogen application on the emergence rate, and the time from sowing to emergence, flowering, and harvest. Applying nitrogen extended the total growth duration of quinoa from 4.0 to 7.8 days compared to the $0 \mathrm{~kg}$ $\mathrm{N} \mathrm{ha}^{-1}$ treatment. However, no differences were found between the low nitrogen applied treatments ( 30 and $60 \mathrm{~kg} \mathrm{~N} \mathrm{ha}^{-1}$ ) and between the high nitrogen applied treatments $(90$ and $150 \mathrm{~kg}$ $\left.\mathrm{N} \mathrm{ha}^{-1}\right)$.

Effects of salt stress and nitrogen application on the growth of quinoa under net-house conditions in the 2017 winter cropping season in Gia Lam, Hanoi

The effects of salt stress and nitrogen application dose on quinoa's growth during the 2017 winter cropping season are illustrated in Table 2. It shows that all the growth parameters of quinoa including plant height, number of leaves/main stem, number of branches/plants, and plant diameter reduced significantly under saline conditions. The results also indicated a positive impact of nitrogen application on quinoa growth. Across two salt levels, plant height, number of leaves/main stem, number of branches/plants, and plant diameter had upward trends and reached the highest values when the nitrogen dose increased from 0 to $90 \mathrm{~kg} \mathrm{~N} \mathrm{ha}^{-1}$, but then reduced when the nitrogen dose increased up to $150 \mathrm{~kg} \mathrm{~N} \mathrm{ha}^{-1}$. 
Table 1. Effects of salt stress and nitrogen application on the emergence rate and growing duration of quinoa in the 2017 winter cropping season in Gia Lam, Hanoi

\begin{tabular}{|c|c|c|c|}
\hline \multirow{2}{*}{ Treatment } & \multicolumn{3}{|c|}{ Days from sowing to } \\
\hline & Emergence & Flowering & Harvest \\
\hline \multicolumn{4}{|c|}{ Salt regimes } \\
\hline Non-stress & $2.1^{\mathrm{a}}$ & $31.4^{\mathrm{a}}$ & $98.5^{\mathrm{b}}$ \\
\hline Stress & $2.1^{\mathrm{a}}$ & $31.7^{a}$ & $100.5^{\mathrm{a}}$ \\
\hline \multicolumn{4}{|c|}{ Nitrogen levels } \\
\hline $0 \mathrm{~N}$ & $2.2^{\mathrm{a}}$ & $31.2^{b}$ & $95.2^{d}$ \\
\hline $30 \mathrm{~N}$ & $2.0^{\mathrm{a}}$ & $31.5^{\mathrm{ab}}$ & $99.2^{\mathrm{c}}$ \\
\hline $60 \mathrm{~N}$ & $2.2^{\mathrm{a}}$ & $31.5^{\mathrm{ab}}$ & $99.5^{\mathrm{c}}$ \\
\hline $90 \mathrm{~N}$ & $2.0^{\mathrm{a}}$ & $32.0^{\mathrm{a}}$ & $100.8^{a}$ \\
\hline $150 \mathrm{~N}$ & $2.0^{\mathrm{a}}$ & $31.7^{\mathrm{ab}}$ & $103.0^{\mathrm{a}}$ \\
\hline
\end{tabular}

Note: Means followed by the same lowercase letter in a column are not significantly different at the $5 \%$ level by LSD.

Table 2. Effects of salt stress and nitrogen application on plant height, number of leaves on the main stem, number of branches on the plant, and plant diameter of quinoa in the 2017 winter cropping season in Gia Lam, Hanoi

\begin{tabular}{|c|c|c|c|c|}
\hline Treatment & $\begin{array}{l}\text { Plant height } \\
\text { (cm) }\end{array}$ & $\begin{array}{l}\text { Number of leaves/ } \\
\text { main stem (leaves) }\end{array}$ & $\begin{array}{l}\text { Number of branches } \\
\text { (branches) }\end{array}$ & $\begin{array}{l}\text { Plant diameter } \\
(\mathrm{cm})\end{array}$ \\
\hline \multicolumn{5}{|c|}{ Salt regimes } \\
\hline Non-stress & $72.9^{a}$ & $33.1^{\mathrm{a}}$ & $11.7^{\mathrm{a}}$ & $0.87^{a}$ \\
\hline Stress & $52.7^{b}$ & $31.5^{\mathrm{b}}$ & $9.6^{b}$ & $0.78^{\mathrm{b}}$ \\
\hline \multicolumn{5}{|c|}{ Nitrogen levels } \\
\hline $0 \mathrm{~N}$ & $59.9^{d}$ & $30.6^{d}$ & $10.1^{c}$ & $0.78^{d}$ \\
\hline $30 \mathrm{~N}$ & $61.7^{c}$ & $31.7^{c}$ & $10.5^{\mathrm{b}}$ & $0.81^{\mathrm{c}}$ \\
\hline $60 \mathrm{~N}$ & $63.8^{\mathrm{b}}$ & $32.8^{\mathrm{b}}$ & $10.8^{\mathrm{b}}$ & $0.83^{b}$ \\
\hline $90 \mathrm{~N}$ & $65.3^{a}$ & $33.6^{\mathrm{a}}$ & $11.4^{\mathrm{a}}$ & $0.86^{a}$ \\
\hline $150 \mathrm{~N}$ & $63.4^{\mathrm{b}}$ & $32.9^{\mathrm{b}}$ & $10.6^{b}$ & $0.84^{\mathrm{b}}$ \\
\hline
\end{tabular}

Note: Means followed by the same lowercase letter in a column are not significantly different at the $5 \%$ level by LSD.

Effects of salt stress and nitrogen application on the yield of quinoa under net-house conditions in the 2017 winter cropping season in Gia Lam, Hanoi

The results showed that dry matter accumulation, panicle length, 1000-seed weight, and individual yield reduced significantly under saline conditions (Table 3). There was a positive impact of nitrogen application on the investigated parameters. Across the two salt levels, the 1000-seed weight and individual yield had upward trends and reached the highest values when the nitrogen dose was increased from 0 to $90 \mathrm{~kg} \mathrm{~N} \mathrm{ha}^{-1}$, but then reduced when the nitrogen level further increased to $150 \mathrm{~kg} \mathrm{~N} \mathrm{ha}^{-1}$. The difference in panicle length was not significant among all the nitrogen treatments, whereas dry matter accumulation did not increase significantly when the nitrogen levels increased from 60 to $90 \mathrm{~kg} \mathrm{~N} \mathrm{ha}^{-1}$ (Table 3).

Effects of salt stress and applied nitrogen doses on the growth duration of quinoa varieties in the 2018 spring cropping season under natural field salinity

As presented in Table 4, there was a difference between the growing duration of the two investigated varieties The average days from sowing to emergence, to flowering, and to harvesting in the 2018 spring cropping season 
Table 3. Effects of salt stress and nitrogen application on dry matter accumulation, panicle length, 1000-seed weight, and individual yield of quinoa in the 2017 winter cropping season in Gia Lam, Hanoi

\begin{tabular}{|c|c|c|c|c|}
\hline Treatment & $\begin{array}{l}\text { Dry matter } \\
\text { accumulation } \\
\left(\text { g plant }^{-1}\right)\end{array}$ & $\begin{array}{l}\text { Panicle length } \\
\text { (cm) }\end{array}$ & $\begin{array}{c}\text { 1000-seed weight } \\
\text { (g) }\end{array}$ & $\begin{array}{l}\text { Individual yield } \\
\left.\qquad \text { (g plant }^{-1}\right)\end{array}$ \\
\hline \multicolumn{5}{|c|}{ Salt regimes } \\
\hline Non-stress & $8.2^{\mathrm{a}}$ & $11.5^{\mathrm{a}}$ & $2.03^{a}$ & $6.60^{\mathrm{a}}$ \\
\hline Stress & $6.1^{b}$ & $8.3^{b}$ & $1.67^{b}$ & $4.74^{\mathrm{b}}$ \\
\hline \multicolumn{5}{|c|}{ Nitrogen levels } \\
\hline $0 N$ & $6.7^{\mathrm{d}}$ & $8.8^{\mathrm{a}}$ & $1.70^{d}$ & $5.14^{d}$ \\
\hline $30 \mathrm{~N}$ & $7.0^{c}$ & $9.4^{\mathrm{a}}$ & $1.79^{c}$ & $5.48^{c}$ \\
\hline $60 \mathrm{~N}$ & $7.3^{\mathrm{ab}}$ & $10.2^{\mathrm{a}}$ & $1.88^{\mathrm{b}}$ & $5.79^{b}$ \\
\hline $90 \mathrm{~N}$ & $7.5^{\mathrm{a}}$ & $10.9^{a}$ & $1.98^{\mathrm{a}}$ & $6.09^{a}$ \\
\hline $150 \mathrm{~N}$ & $7.2^{\mathrm{bc}}$ & $10.4 a$ & $1.91^{\mathrm{b}}$ & $5.84^{\mathrm{b}}$ \\
\hline
\end{tabular}

Note: Means followed by the same lowercase letter in a column are not significantly different at the $5 \%$ level by LSD.

Table 4. Effects of salt stress and nitrogen application on the growth duration of quinoa varieties in the 2018 spring cropping season in Hai Hau, Nam Dinh

\begin{tabular}{|c|c|c|c|}
\hline \multirow{2}{*}{ Treatment } & \multicolumn{3}{|c|}{ Days from sowing to } \\
\hline & Emergence & Flowering & Harvest \\
\hline \multicolumn{4}{|c|}{ Varieties } \\
\hline Atlas & $3.8 \mathrm{a}$ & $56.4 a$ & $105.8 \mathrm{a}$ \\
\hline Moradas & 3.3a & $54.5 b$ & $91.8 b$ \\
\hline \multicolumn{4}{|c|}{ Nitrogen levels } \\
\hline $0 N$ & 3.3a & $54.3 \mathrm{c}$ & $98.0 \mathrm{~b}$ \\
\hline $30 \mathrm{~N}$ & $3.7 \mathrm{a}$ & $54.7 \mathrm{c}$ & $98.0 \mathrm{~b}$ \\
\hline $60 \mathrm{~N}$ & $3.7 \mathrm{a}$ & $54.7 \mathrm{c}$ & $98.5 b$ \\
\hline $90 \mathrm{~N}$ & $3.5 \mathrm{a}$ & $56.3 b$ & $99.5 a$ \\
\hline $150 \mathrm{~N}$ & $3.5 a$ & $57.2 a$ & $100.0 \mathrm{a}$ \\
\hline
\end{tabular}

Note: Means followed by the same lowercase letter in a column are not significantly different at the $5 \%$ level by LSD.

were $3.3,56.4$, and 105.8 days, respectively, for Atlas, and 3.3, 54.5, and 91.8 days, respectively, for Moradas. The times to emergence, flowering, and harvest of Moradas were earlier than those of Atlas. The duration times of Atlas were longer than those of Moradas, but significant differences were found only in the times from sowing to flowering and harvesting. The results also indicated that the growth duration of both quinoa varieties was extended, but just in the treatments of high nitrogen application doses of 90 and $150 \mathrm{~kg} \mathrm{~N} \mathrm{ha}^{-1}$. The times from sowing to flowering and harvesting were similar when nitrogen was applied at lower doses from 0 to 60 $\mathrm{kg} \mathrm{N} \mathrm{ha}{ }^{-1}$.
Effects of salt stress and applied nitrogen doses on the growth of quinoa varieties in the 2018 spring cropping season under natural field salinity in Hai Hau, Nam Dinh

The results showed that plant height, number of leaves on the main stem, number of branches/plants, and plant diameter of the quinoa varieties were significantly different. Moradas had greater values than Atlas in all the indicators (Table 5). Applying nitrogen at different rates induced differences in the growth parameters across the two quinoa varieties. The values of these parameters reached the highest at the nitrogen application dose of $90 \mathrm{~kg} \mathrm{~N} \mathrm{ha}^{-1}$ (Table 5), then reduced when the nitrogen level was increased up to $150 \mathrm{~kg} \mathrm{~N}$ ha $^{-1}$. 
Effects of salt stress and applied nitrogen doses on lodging resistance and insect infection rates of quinoa in the 2018 spring cropping season under natural field salinity in Hai Hau, Nam Dinh

In the 2018 spring cropping season, no diseases or the lodging phenomenon were detected, and the severity for some major worms including black cutworm and green clover worm were at similar and moderate rates both in both varieties (Table 6). The highest infection rate with black cutworm was recorded at the treatment of $150 \mathrm{~kg} \mathrm{~N} \mathrm{ha}^{-1}$ and was significantly higher than other treatments except for $90 \mathrm{~kg} \mathrm{~N}$ $\mathrm{ha}^{-1}$. At the treatment of $60 \mathrm{~kg} \mathrm{~N} \mathrm{ha}{ }^{-1}$, the infection rate with clover worm was higher than all the other treatments.

Effects of salt stress and applied nitrogen doses on the yield components of quinoa in the 2018 spring cropping season under natural field salinity in Hai Hau, Nam Dinh

The data in Table 7 show the influence of nitrogen levels to the yield and yield components of the quinoa varieties. The table illustrates that there were no significant differences in the number of panicles and actual yield between the two varieties. In contrast, head panicle length, 1000 -seed weight, and individual yield of the quinoa varieties were significantly different.
Moradas had a higher head panicle length and 1000 -seed weight, but lower individual seed yield than Atlas did. The results of the study also showed that different nitrogen application levels led to differences in all the indicators. The values of all the target indicators increased and reached the highest when the nitrogen application dose was increased to $90 \mathrm{~kg} \mathrm{~N}^{-1}$.

\section{Discussions}

This study showed that salt concentrations $(100 \mathrm{mM} \mathrm{NaCl})$ in irrigated water nonsignificantly affected the seed emergence rate and growth duration of quinoa (Table 1). The salt stress reduced plant height, the number of leaves on the main stem, the number of branches on the plant, and the plant diameter (Table 2). The dry matter accumulation, panicle length, number of panicles on the plant, 1000-seed weight, and individual yield also declined significantly under the effects of saline conditions (Table 3). Under artificial salt stress conditions for 14 days at the flowering stage, Nguyen Viet Long (2016b) also indicated that increasing the salt concentration reduced the morphological traits and yield components of quinoa varieties. Our results were in agreement with the findings of Nguyen Viet Long (2016a) about plant height, the number of branches on the plant, the number of leaves on

Table 5. Effects of salt stress and nitrogen application on plant height, number of leaves on the main stem, number of branches on the plant, and plant diameter of quinoa varieties in the 2018 spring cropping season in Hai Hau, Nam Dinh

\begin{tabular}{|c|c|c|c|c|}
\hline Treatment & $\begin{array}{l}\text { Plant height } \\
\quad(\mathrm{cm})\end{array}$ & $\begin{array}{l}\text { Leaves number/ } \\
\text { main stem } \\
\text { (leaves) }\end{array}$ & $\begin{array}{c}\text { Number of branches } \\
\text { (branches) }\end{array}$ & $\begin{array}{c}\text { Plant diameter } \\
(\mathrm{cm})\end{array}$ \\
\hline \multicolumn{5}{|c|}{ Varieties } \\
\hline Atlas & $72.0^{\mathrm{b}}$ & $32.7^{\mathrm{b}}$ & $22.9^{b}$ & $1.10^{\mathrm{b}}$ \\
\hline Moradas & $82.1^{a}$ & $35.5^{a}$ & $24.7^{a}$ & $1.15^{a}$ \\
\hline \multicolumn{5}{|c|}{ Nitrogen levels } \\
\hline $0 N$ & $66.5^{\mathrm{e}}$ & $31.6^{c}$ & $20.7^{c}$ & $0.91^{d}$ \\
\hline $30 \mathrm{~N}$ & $71.8^{d}$ & $31.9^{c}$ & $23.3^{\mathrm{b}}$ & $1.06^{c}$ \\
\hline $60 \mathrm{~N}$ & $76.5^{c}$ & $34.0^{\mathrm{b}}$ & $23.7^{b}$ & $1.10^{c}$ \\
\hline $90 \mathrm{~N}$ & $86.9^{a}$ & $37.3^{a}$ & $26.0^{\mathrm{a}}$ & $1.31^{\mathrm{a}}$ \\
\hline $150 \mathrm{~N}$ & $83.4^{\mathrm{b}}$ & $35.6^{b}$ & $25.4^{\mathrm{a}}$ & $1.24^{\mathrm{b}}$ \\
\hline
\end{tabular}

Note: Means followed by the same lowercase letter in a column are not significantly different at the $5 \%$ level by LSD. 
Table 6. Effects of salt stress and nitrogen application on the resistance to lodging and infection rate of black cutworm and clover worm of quinoa varieties in the 2018 spring cropping season in Hai Hau, Nam Dinh

\begin{tabular}{lccc} 
Treatment & $\begin{array}{c}\text { Resistance to lodging } \\
(1-5)^{*}\end{array}$ & $\begin{array}{c}\text { Black cutworm } \\
(1-5)^{* *}\end{array}$ & $\begin{array}{c}\text { Clover worm } \\
(1-5)^{* *}\end{array}$ \\
\hline & & Varieties & $2.6^{\mathrm{a}}$ \\
Atlas & $1.0^{\mathrm{a}}$ & $2.4^{\mathrm{a}}$ & $2.6^{\mathrm{a}}$ \\
Moradas & $1.0^{\mathrm{a}}$ & $2.2^{\mathrm{a}}$ & $2.5^{\mathrm{bc}}$ \\
& & Nitrogen levels & $2.5^{\mathrm{bc}}$ \\
$30 \mathrm{~N}$ & $1.0^{\mathrm{a}}$ & $2.0^{\mathrm{c}}$ & $3.0^{\mathrm{a}}$ \\
$60 \mathrm{~N}$ & $1.0^{\mathrm{a}}$ & $2.2^{\mathrm{b}}$ & $2.3^{\mathrm{c}}$ \\
$90 \mathrm{~N}$ & $1.0^{\mathrm{a}}$ & $2.2^{\mathrm{b}}$ & $2.7^{\mathrm{b}}$ \\
\hline
\end{tabular}

Note: * 1 - no lodging, 5 - heavy shedding; ${ }^{* *} 1$ - not infected, 5 - serious infection; means followed by the same lowercase letter in a column are not significantly different at the $5 \%$ level by $L S D$.

Table 7. Effects of salt stress and nitrogen application on the yield and yield components of quinoa varieties in the 2018 spring cropping season in Hai Hau, Nam Dinh

\begin{tabular}{|c|c|c|c|c|c|}
\hline Treatment & $\begin{array}{l}\text { Number of panicles } \\
\text { (panicles) }\end{array}$ & $\begin{array}{l}\text { Head panicle length } \\
(\mathrm{cm})\end{array}$ & $\begin{array}{l}\text { 1000-seed weight } \\
(\mathrm{g})\end{array}$ & $\begin{array}{l}\text { Individual } \\
\text { yield } \\
\left.\text { (g plant }^{-1}\right)\end{array}$ & $\begin{array}{c}\text { Actual } \\
\text { yield } \\
\text { (tons ha-1) }^{-1} \text {. }\end{array}$ \\
\hline \multicolumn{6}{|c|}{ Varieties } \\
\hline Atlas & 17.3 & $22.7^{b}$ & $2.44^{b}$ & $22.4^{\mathrm{a}}$ & 1.17 \\
\hline Moradas & 17.5 & $23.4^{\mathrm{a}}$ & $2.51^{\mathrm{a}}$ & $21.3^{b}$ & 1.15 \\
\hline \multicolumn{6}{|c|}{ Nitrogen levels } \\
\hline $0 \mathrm{~N}$ & $13.2^{\mathrm{e}}$ & $20.3^{c}$ & $2.35^{\mathrm{e}}$ & $15.3^{\mathrm{e}}$ & $0.86^{d}$ \\
\hline $30 N$ & $15.2^{d}$ & $23.0^{\mathrm{b}}$ & $2.43^{d}$ & $18.2^{d}$ & $1.09^{c}$ \\
\hline $60 \mathrm{~N}$ & $17.3^{\mathrm{c}}$ & $23.1^{\mathrm{b}}$ & $2.48^{\mathrm{c}}$ & $22.7^{c}$ & $1.24^{b}$ \\
\hline $90 \mathrm{~N}$ & $21.3^{a}$ & $25.7^{a}$ & $2.59^{\mathrm{a}}$ & $27.2^{\mathrm{a}}$ & $1.35^{\mathrm{a}}$ \\
\hline $150 \mathrm{~N}$ & $19.9^{b}$ & $23.2^{\mathrm{b}}$ & $2.54^{b}$ & $25.8^{b}$ & $1.25^{\mathrm{b}}$ \\
\hline
\end{tabular}

Note: Means followed by the same lowercase letter in a column are not significantly different at the $5 \%$ level by LSD.

the main stem, and the head panicle length under artificial salt stress conditions. Previous studies showed similar results in that plant height, dry matter accumulation, seed number, seed weight, and grain yield were reduced under the effects of saline stress (Jacobsen et al., 2001; Koyro \& Eisa, 2008; Gómez-Pando et al., 2010; RuizCarrasco et al., 2011; Razzaghi et al., 2012; Eisa et al., 2012; Bonales-Alatorre et al., 2013; Peterson \& Murphy, 2014; Panuccio et al., 2014).

In this research, applying nitrogen at a different doses in the winter cropping season did not have any effect on the time from sowing to flowering, but extended the total growth duration (Table 1). This could be explained that in the 
winter cropping season, plant growth was accelerated due to high temperatures at the early stages of development, so the impacts of fertilizer were negligibly noticeable which led to similar flowering times in all the fertilized treatments. However, at the later stages of development, when the influence of fertilizer becomes more significant, increasing the nitrogen levels resulted in better plant growth along with longer growth duration. In the spring cropping season, the time from sowing to flowering as well as the total growth duration tended to increase as the nitrogen level was increased (Table 4). Dinh Thai Hoang et al. (2015) also indicated that when the amount of nitrogen fertilizer was increased, the time from sowing to flowering and the total growth duration of the investigated quinoa varieties were not affected in the winter cropping season, but in the spring cropping season, they were extended from 1 to 3 days. Basra et al. (2014) also reported similar results that increasing the amount of fertilizer from 0 to $125 \mathrm{~kg} \mathrm{~N}^{-1}$ did not affect the flowering time but extended the total growth duration. In this study, under net-house conditions with both salinity levels, the growth ability and yield of quinoa increased when the amount of nitrogen application increased from 0 to $90 \mathrm{~kg} \mathrm{~N} \mathrm{ha}^{-1}$, and decreased when the fertilizer amount reached $150 \mathrm{~kg} \mathrm{~N}^{-1}$ (in the first experiment). Similar results were found in the second experiment for the two quinoa varieties conducted under natural saline conditions in Hai Hau, Nam Dinh province. In Hanoi, under nonsaline alluvial land of the Red River Delta, Dinh Thai Hoang et al. (2015) also showed similar results when nitrogen was applied in the range of 0 to $102 \mathrm{~kg} \mathrm{~N} \mathrm{ha}^{-1}$, plant height, plant diameter, SPAD index, dry weight accumulation, and yield of quinoa varieties reached the highest values at a rate of $90 \mathrm{~kg} \mathrm{~N} \mathrm{ha}^{-1}$. However, the optimum amount of fertilizer depends on the specific conditions of each region. Basra et al. (2014) reported that the 1000-seed weight, the number of panicles per plant, and the grain yield of quinoa increased when the nitrogen doses were increased from 0 to $75 \mathrm{~kg} \mathrm{~N} \mathrm{ha}^{-1}$. An experiment with the five nitrogen levels of $0,90,180,270$, and $360 \mathrm{~kg} \mathrm{~N} \mathrm{ha}^{-1}$ on sandy soils in Egypt, Shams
(2012) stated that the grain yield of quinoa was maximized when nitrogen was applied at a rate of $90 \mathrm{~kg} \mathrm{~N} \mathrm{ha}^{-1}$. Therefore, it could be concluded that the growth and yield of quinoa increase to their maximum when the nitrogen application level reaches the optimum level, then begin to decrease if the nitrogen level is further increased. The optimum nitrogen application level for the coastal provinces in the Northern part of Vietnam is $90 \mathrm{~kg} \mathrm{~N} \mathrm{ha}^{-1}$.

\section{Conclusions}

Saline stress had no effect on quinoa growth duration, but reduced the growth and yield parameters of the quinoa cultivars. Similar trends were found in the response of quinoa to the nitrogen application rates in both experiments, particularly in the increases of plant height, number of leaves on the main stem, number of branches, stem diameter, dry matter accumulation, panicle length, panicle number, 1000 -seed weight, individual yield, and actual yield of the quinoa cultivars according to the increase of nitrogen application rates from 0 to $90 \mathrm{~kg} \mathrm{~N} \mathrm{ha}^{-1}$. The application dosage $90 \mathrm{~kg} \mathrm{~N} \mathrm{ha}^{-1}$ was recommended as the optimum dose of nitrogen application for quinoa grown under saline soil conditions in Northern Vietnam.

\section{Acknowledgments}

This study was supported by grants from the Vietnamese Ministry of Science and Technology (Grant-in-Aid for evaluation of quinoa in different ecological conditions in Vietnam HNQT/SPDP/07.17). We also thank Dr. Daniel Bertero (Buenos Aires University, Argentina) and Dr. Robert Van Loo (Wageningen UR, the Netherlands) for providing the quinoa genotypes for this study.

\section{References}

Basra S. M. A., Iqbal S. \& Afzal I. (2014). Evaluating the response of nitrogen application on growth, development and yield of quinoa Varieties. International Journal of Agriculture and Biology. 16: 886-892. 
Bertero H. D., Vega A. J. D. L., Correa G., Jacobsen S. E. \& Mujica A. (2004). Genotype and genotype-byenvironment interaction effects for grain yield and grain size of quinoa (Chenopodium quinoa Willd.) as revealed by pattern analysis of international multienvironment trials. Field Crop Research. 89: 299-318.

Bioversity International (2013). Descriptors for quinoa and relatives. Retrieved from http://www.bioversityinternational.org/fileadmin/user _upload/online_library/publications/pdfs/Descriptors_ for_quinoa_Chenopodium_quinoa_Willd__and_wi ld_relatives_1679.pdf on February 3, 2020.

Bonales-Alatorre E., Pottosin I., Shabala L., Chen Z. H., Zeng F., Jacobsen S. E. \& Shabala S. (2013). Differential activity of plasma and vacuolar membrane transporters contributes to genotypic differences in salinity tolerance in a halophyte species, Chenopodium quinoa. International Journal of Molecular Sciences. 14: 9267- 9285.

Dinh Thai Hoang, Nguyen Tat Canh \& Nguyen Viet Long. (2015). Effect of nitrogen on growth and yield of introduced quinoa accessions. Journal of Science and Development. 13(2): 173-182.

Eisa S., Hussin S., Geisseler N. \& Koyro H. W. (2012). Effects of $\mathrm{NaCl}$ salinity on water relations, photosynthesis and chemical composition of quinoa (Chenopodium quinoa Willd.) as a potential cash crop halophyte. Australian Journal of Crop Science. 6: 357368.

FAO (Food Agriculture Organization of the United Nations) (2011). Quinoa: An ancient crop to contribute to world food security.

FAO (2013). International year of quinoa. Retrieved from http://www.fao.org/quinoa-2013/en on February 20, 2020.

Gómez-Pando L. R., Álvarez-Castro R. \& Eguiluz-de la Barra A. (2010). Effect of salt stress on Peruvian germplasm of Chenopodium quinoa Willd.: A promising crop. Journal of Agronomy and Crop Science. 196: 391-395.

Jacobsen S. E., Quispe H. \& Mujica A. (2001). Quinoa: an alternative crop for saline soils in Andes. In: Scientist and Farmer-partner in Research for the $21^{\text {st }}$ Century. CIP Program Report 1999-2000. 403-408.

Koyro H. W. \& Eisa S. S. (2008). Effect of salinity on composition, viability and germination of seeds of
Chenopodium quinoa Willd. Plant and Soil. 302: 7990.

Nguyen Van Dao \& Ho Quang Duc. (2019). Saline soil in Vietnam. Results of scientific study and extension, Soils and Fertilizers Research Institute. Agricultural Publisher, Hanoi, Vietnam. 95-106 (in Vietnamese).

Nguyen Viet Long (2016a). Genetic variation in response to salt stress of quinoa grown under controlled and field conditions. International Journal on Advanced Science Engineering Information Technology. 6(2): 233-238.

Nguyen Viet Long (2016b). Effects of salinity stress on growth and yield of quinoa (Chenopodium quinoa Willd.) at flower initiation stages. Vietnam Journal of Agricultural Science. 14(3): 321-327.

Panuccio M. R., Jacobsen S. E., Akhtar S. S. \& Muscolo A. (2014). Effect of saline water on seed germination and early seedling growth of the halophyte quinoa. Journal of Plant Science. DOI: 10.1093/abobpla/plu047.

Peterson A. \& Murphy K. (2014). Tolerance of lowland quinoa varieties to sodium chloride and sodium sulfate salinity. Crop Science. DOI: 10.2135/cropsci2014.04.0271.

Razzaghi F., Ahmadi S. H., Jacobsen S. E., Jensen C. R. \& Andersen M. N. (2012). Effects of salinity and soildrying on radiation use efficiency, water productivity and yield of quinoa (Chenopodium quinoa Willd.) Journal of Agronomy and Crop Science. 198: 173184.

Ruiz-Carrasco K., Antognoni F., Coulibaly A. K., Lizardi S., Covarrubias A., Martínez E. A., MolinaMontenegro M. A., Biondi S. \& Zurita-Silva A. (2011). Variation in salinity tolerance of four lowland Varieties of quinoa (Chenopodium quinoa Willd.) as assessed by growth, physiological traits, and sodium transporter gene expression. Plant Physiology and Biochemistry. 49: 1333-1341.

Shams A. S. (2012). Response of quinoa to nitrogen fertilizer rates under sandy soil conditions. Proceeding of $13^{\text {th }}$ International Conference of Agronomy, Faculty of Agriculture, Benha University, Egypt, September 910, 2012. 195-205.

Trinh Ngoc Duc (2001). Study to develop quinoa (Chenopodium quinoa Willd) in the northern part of Vietnam. Doctoral thesis. Hanoi University of Agriculture. 53-84 (in Vietnamese). 